\title{
Geology and Geochemistry of Zungeru Amphibolites, North Central Nigeria
}

\author{
Ako Thomas Agbor \\ Department of Geology, School of Natural and Applied Sciences, Federal University of Technology, Minna, Nigeria \\ *Corresponding Author: akoagbor@futminna.edu.ng
}

Copyright (C) 2014 Horizon Research Publishing All rights reserved.

\begin{abstract}
Basement rocks of Zungeru area consist of gneisses, schists, migmatites and intercalations of amphibolites and quartzites .This work involves detailed geological and geochemical investigation of Zungeru amphibolites so as to reveal their possible protolith. Field investigations show two petrographic types of the amphibolites on the basis of their textures, structures and mineralogy. They include the banded and massive types. The banded type is medium grained, strongly foliated and dark coloured rock while the massive type is fine to medium grained, dark-grey to black coloured with very weak foliations. Both types have been fractured due to deformation resulting in the development of joints and faults. Twelve representative samples of the amphibolites in the study area were collected and analyzed for major and trace elements using the Energy Dispersive X-Ray Fluorescence (EDX-RF) Spectrometer, Model: Minipal 4 at the laboratory of the National Geological Agency, Kaduna. However, only the major elements data was used for determination of the protolith of the amphibolites. The analytical results show that the Zungeru amphibolites contain on average $50.15 \%$ $\mathrm{SiO}_{2}, 12 \% \quad \mathrm{Al}_{2} \mathrm{O}_{3}, 0.39 \% \quad \mathrm{Na}_{2} \mathrm{O}, 0.02 \% \quad \mathrm{~K}_{2} \mathrm{O}, 9.41 \% \mathrm{CaO}$, 9.90\% $\mathrm{MgO}, 0.02 \% \mathrm{MnO}, 12.24 \% \mathrm{Fe}_{2} \mathrm{O}_{3}, 4.89 \% \mathrm{FeO}, 0.5 \%$ $\mathrm{TiO}_{2}, 0.10 \% \mathrm{P}_{2} \mathrm{O}_{5}$ and $0.78 \% \mathrm{H}_{2} \mathrm{O}$. Various bivariate plots indicate that the precursors of the amphibolites are sedimentary. They are inferred to have been formed from metamorphism of decarbonated mixtures of pelitic sediments and calcite or dolomite. The occurrence of the amphibolites in association with quartzites further strengthened the fact that their origin is sedimentary and therefore referred to as para-amphibolites.
\end{abstract}

Keywords Amphibolites, Protholith, Bivariate Plots, Zungeru, Para-amphibolites, Basement Complex

\section{Introduction}

The Precambrian basement complex rocks of Nigeria are categorized into three sub-divisions. These are ancient migmatite-gneiss-quartzite complex, the schist belts and Pan
African (600 ma) granitic series commonly called older granite suites. The most pervasive tectonic fabric of igneous reactivation of this suite is attributed to Pan-African event. This Precambrian crystalline basement complex covers nearly $60 \%$ of land surface of Nigeria and extends to neighboring countries. The migmatite-gneiss complex makes up about $60 \%$ of surface area of Nigeria basement. These rocks recorded at least four major tectonic cycles of deformation, metamorphism and remobilization in the Liberian, Eburnean, Kibarian and Pan-Africa, thus, confirming Russ's view of age of determination from various part of the Nigeria basement. The migmatite-gneiss complex rocks are believed to be basement rocks in real sense. Investigation into the basement area in other parts of the country by [1, 2, 3, 4 and 5] suggested that the pelitic and semi-pelitic younger meta-sediments in Nigeria were deposited between 800 and 1000 million years ago. Age determination across the country shows that the migmatite-gneiss complex contains rocks that are younger that are as young as 600 million years and those that are as old as 300 billion years. This will appear as if there are several generations of migmatite-gneiss complex, much of which has been formed during the orogenic cycle. The migmatite-gneiss includes rocks of varying composition, texture and structure containing metamorphic host rock (palaesome) and leucocratic acid injection (metasome). These rocks are believed to have originated or formed as a result of progressive regional metamorphism of meta-sedimentary rocks [6] and the presence of meta-conglomerate indicates formation from the surrounding materials. The schist belts consist of north-south trending rocks which occur prominently in the western part of Nigeria. These rocks show distinctive petrological and structural features. There are numerous belts in the north-west while other in the south-west including Iseyin, Igarra-Okene and Egbe-Insanlu schist belts. The Toto-Gadabuike schist belt hosts the Burum-Takalafia amphibolites [7)] and the ones in the south eastern part of the country [8] are the occurrence recently highlighted. The schist belts composed of metamorphosed pelitic and psammatic assemblages. Secondary lithologies such as ferruginous iron (banded iron formation); carbonates and 
mafic-ultramafic bodies are often used in discriminating them. These belts are considered as upper Proterozoic supercrustal rocks which have been infolded into the migmatite-gneiss complex. The schist belts and gneissic complex have parallel structure and no unconformity has been mapped between them. Russ [9] considered that the schist belts were deposited on the gneissic complex. Other workers like [10 and 11] disputed Russ's view and drew their conclusion from polycyclic evolution model of the basement. Ajibade et al, [12] identified the Zungeru mylonite within the basement and between the gneissic complex and some schist belts meaning that the contact between these belts are tectonic rather than metamorphic. Rocks of older granite series [13] have been found to occur in the mapped area of the Nigeria basement. These rocks are called older granite so as to differentiate them from the younger granites; that is, a high level orogenic Jurassic granites of Jos Plateau in Northern Nigeria. These Pan-Africa rocks represent a varied and long lasting magmatic cycle and intrude both the migmatite-gneiss complex and schist belts [14].

Amphibolites have been reported to occur within the Zungeru mylonites as concordant bands which vary in width from a few centimeters to several meters. These rocks occur throughout the kushaka Formation as intercalations other metapelites, giving rise to sheet-like bodies that range in thickness from about $50 \mathrm{~cm}$ to $20 \mathrm{~m}$ [14]. These rocks present one of the most vexing of the parent rock problems in the origin of rocks in high grade metamorphic terrains. Amphibolites consist primarily of hornblende and plagioclase in sub-equal amounts. Parent rocks of equivalent chemical composition include basalt flows, tuffs, sills and dykes, gabbroic rocks and various combinations of shaly limestone or calcareous rocks. Rocks of equivalent composition may also form by metasomatism of limestone or other rocks. Viewpoint varies about the origin of amphibolites for example, [15, 16, 17 and 18]. So far three main processes of formation have been proposed. These are metamorphism of basic igneous rocks, metamorphism of sediments of suitable composition and metasomatic alteration of pre-existing rocks [15 and 19]. Leake [20] classified meta-igneous amphibolites which are completely re-crystallized dolerites, basalt or basic tuffs; while para-amphibolites are equivalents of decarbonated mixtures of pelitic sediments and calcite or dolomite. In distinguishing between ortho-amphibolites and para-amphibolites, [20] suggested an approach based on geological nature, abundance of elements and their relationship to known igneous and sedimentary trends. This approach is considered a more credible basis of chemical criteria of distinguishing between ortho-amphibolites and para-amphibolites than the absolute concentrated level. Leake [20, 21, 22, and 23] have demonstrated the effective use of plots of Niggli values in distinguishing between ortho-amphibolites and para-amphibolites.

Amphibolites need not be derived from metamorphosed mafic rocks. This is because metamorphism creates minerals based entirely upon the chemistry of the protolith, certain dirty marls and volcanic sediments may actually metamorphose to an amphibolite assemblage. Deposits containing dolomite and siderite also readily yield amphibolites (tremolite-schist, grunerite-schist and others) especially where there has been a certain amount of contact metamorphism by adjacent granitic masses. Amphibolites fall into two groups from point of view of their origin, the para-amphibolites which are altered sediments and the ortho-amphibolites which are modified igneous rocks. The ortho-amphibolites are far more common than the para-amphibolites. This study determines the geology and geochemistry of Zungeru amphibolites using field observations and chemical analysis in order to reveal their field characteristics and protolith.

The area studied is part of Zungeru (Sheet 163) in north central Nigeria. It lies between latitudes $9^{\circ} 46^{\prime} \mathrm{N}$ and $9^{\circ} 52^{\prime} \mathrm{N}$ and Longitudes $6^{\circ} 07^{\prime}$ and $6^{\circ} 13^{\prime} \mathrm{E}$ (Figure 1). It has an area extent of approximately $144 \mathrm{Km}^{2}$ and it is accessible through major roads like the Minna-Zungeru, Zungeru-Wushishi and the Zungeru-Kontagora in the North, West and Southeast respectively. It is also accessible by innumerable minor roads and footpaths. By rail, it is accessible by Zungeru-Minna-Kano rail line to the North and Zungeru-Lagos rail line to the South.

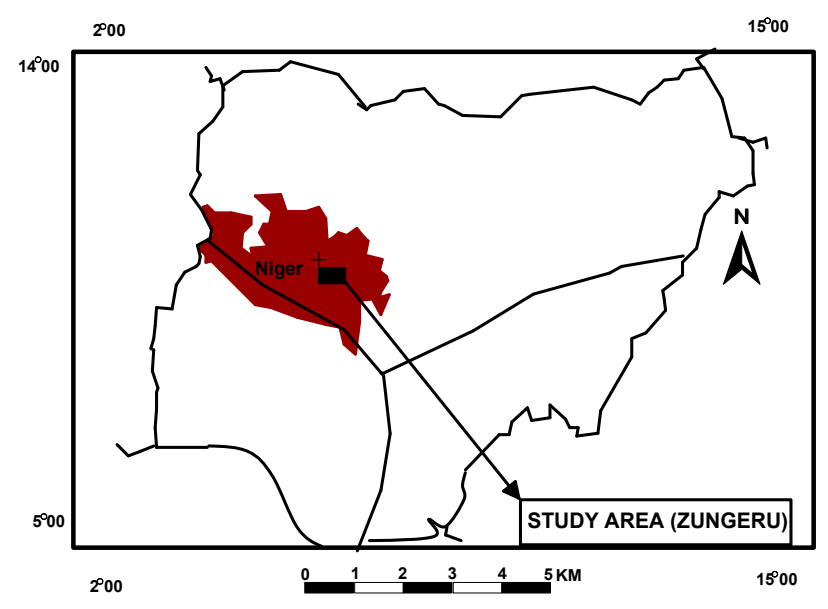

Figure 1. Map of Nigeria Showing Study Area (Zungeru).

\section{Materials and Methods}

The methods of the study consisted of the field and analytical methods. In the field method, amphibolites rocks samples were sampled from the area in which they outcropped the earth's surface. The outcrops together with the samples collected in the field were studied while the representative samples collected were sent to the laboratory for whole-rock geochemical analyses. In the analytical method, the representative samples from the gross lithology of the rocks were crushed, using a small jaw crusher. The crushed samples were later fed into a mechanical agate mortar and pestle and ground into powder after which the sample material was transferred into smaller bottles and labeled with details of the specimen before the analyses. The 
whole-rock geochemical analysis was done in the laboratory of the Nigerian Geological Survey Agency, Kaduna, using $\mathrm{X}$-ray Fluorescence (XRF). Major elements determined in the analyses include $\mathrm{SiO}_{2}, \mathrm{Al}_{2} \mathrm{O}_{3}, \mathrm{Na}_{2} \mathrm{O}, \mathrm{K}_{2} \mathrm{O}, \mathrm{CaO}, \mathrm{MgO}$, $\mathrm{MnO}, \mathrm{Fe}_{2} \mathrm{O}_{3}, \mathrm{TiO}_{2}$ and $\mathrm{P}_{2} \mathrm{O}_{5}$ and were determined according the method described by [24]. The results of the analyses were plotted on various variation diagrams and compared with those of similar studies.

\section{Results}

\subsection{Field Observations}

The rock types encountered in the mapped area include migmatite-gneisses, schists, amphibolites, quartzites and minor granitic intrusions as shown on the geological map (Figure 2). The gneisses occupy most of the study area and include the granite gneiss and the banded (grey) gneiss. Both gneisses have intruded the schist and themselves have in turn been intruded by some granitic intrusions. The gneisses occur as hilly, massive and low lying outcrops, where they form contact with the schists. The schist and amphibolites occupy the central part of the study area and are boarded by approximately N-S trending units of the migmatites-gneiss complex. The contact with the gneisses may be tectonic in places and is marked by development of cataclastics and mylonites. The amphibolites occur in association with quartzites and this association suggests that both rocks must have been sediments deposited and later metamorphosed to form amphibolites and quartzites (Figure 3). Two varieties of amphibolites were revealed in the field. They are the banded and massive varieties. The banded variety is medium grained, strongly foliated and dark green in colour whereas the massive variety is fine to medium grained, weakly foliated and dark grey in colour. [14] have reported large bodies of amphibolite within the study area. They described the contact between the amphibolites and the quartzo-feldsparthic rocks as sharp in some areas while in others the contacts are transitional. The transitional contacts mapped by [9] made him to conclude that the amphibolites were probably derived from calcareous sediments.

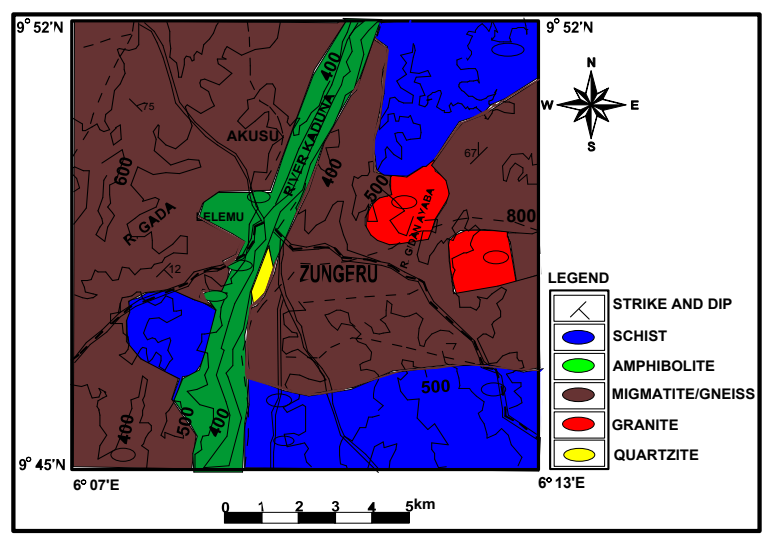

Figure 2. Geological map of the study area

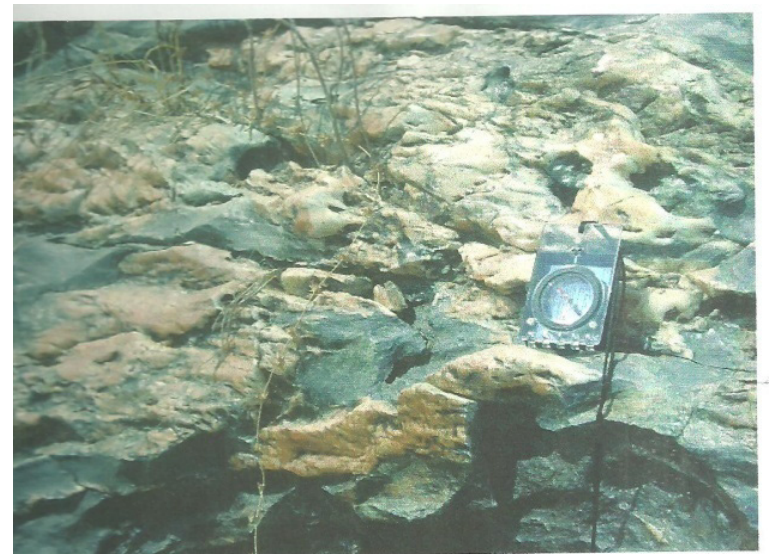

Figure 3. Photograph of association of amphibolites and quartzites probably formed from metamorphism of sediments.

The amphibolites are interpreted to have formed from metamorphism of dolomite, siderite, dirty marls or volcanic sediments while the quartzites from sandstones. The amphibolites contain hornblende, plagioclase and quartz, and are highly foliated or lineated due to preferred orientation of dark and light coloured minerals (Figure 4). The amphibolites occur in N-S position within the central part of the studied area, mainly along the River Kaduna and are bordered in some places by N-S trending units of the gneisses (Figure 5). In some places the amphibolites form contacts with surrounding rocks which are often marked by development of cataclastics and mylonites which represent a major fracture zone within the area (Figure 6) and the fractures are either joint or faults (Figure $7 \mathrm{a}$ and $\mathrm{b}$ ).

\subsection{Laboratory Results}

The results of the chemical analysis are given in details and summarized in averages and ranges of major elements in the samples (Table 1). Results of similar studies conducted in other parts of the world were used for comparism and are presented in table 2 .

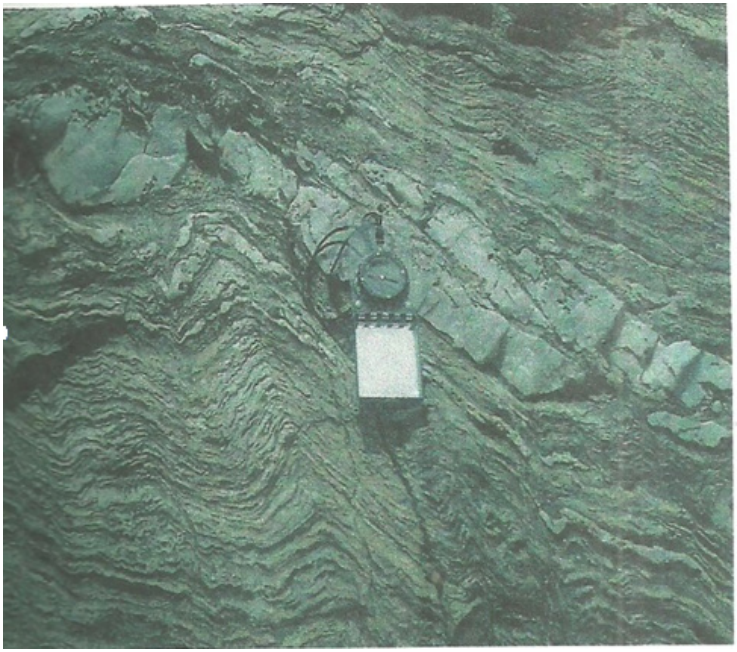

Figure 4. A foliated amphibolite with alteration of dark and light coloured minerals 


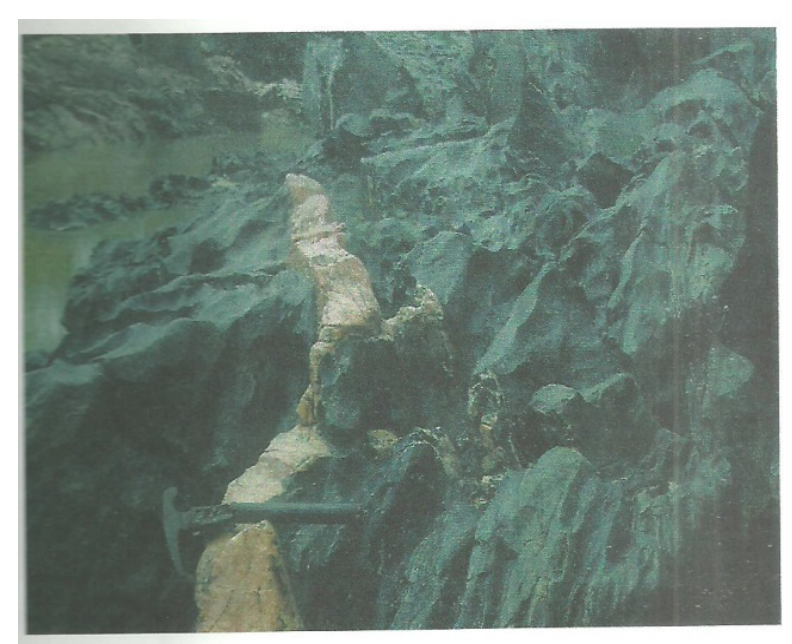

Figure 5. Amphibolite (dark coloured) with N-S trending direction along River Kaduna cross cut by quartzite (light coloured)

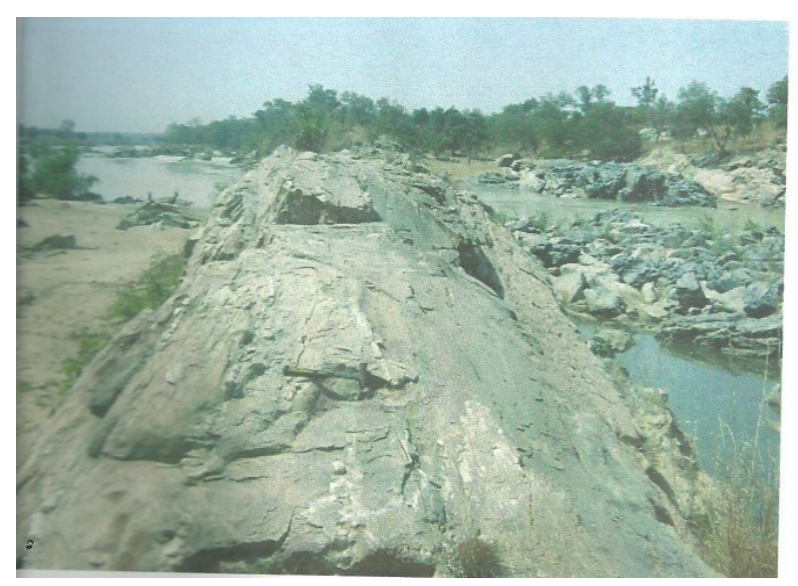

Figure 6. Photograph of mylonite representing a major structural feature trending N-S in the study area

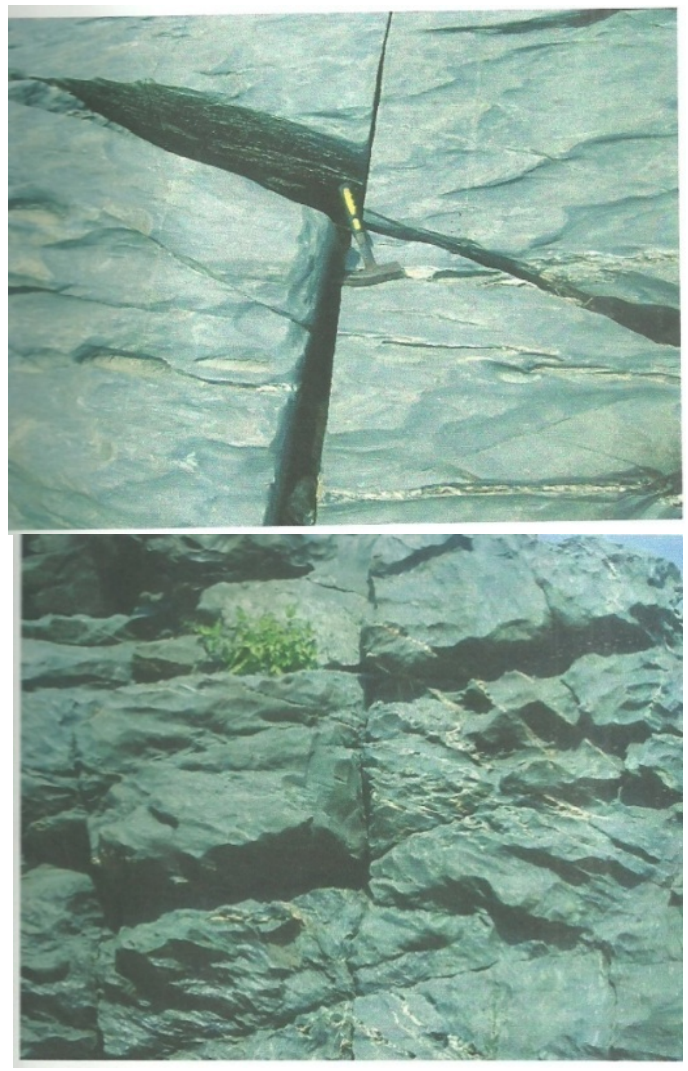

Figure 7. Photographs of fractures,(a) faults and (b) joints that show that the rocks have suffered deformation.

Table 1. Analytical Data of Zungeru Amphibolites Rock Samples

\begin{tabular}{ccccccccc|}
\hline $\begin{array}{c}\text { Oxides } \\
(\%)\end{array}$ & $\mathrm{ZA} 1$ & $\mathrm{ZA} 2$ & $\mathrm{ZA} 3$ & $\mathrm{ZA} 4$ & $\mathrm{ZA} 5$ & $\mathrm{ZA6}$ & Range & $\begin{array}{c}\text { Average } \\
(\%)\end{array}$ \\
$\mathrm{SiO}_{2}$ & 51.03 & 50.43 & 50.71 & 49.31 & 51.03 & 48.41 & $48.41-51.03$ & 50.15 \\
$\mathrm{Al}_{2} \mathrm{O}_{3}$ & 12.12 & 12.35 & 12.07 & 11.07 & 12.36 & 12.08 & $11.07-12.36$ & 12.00 \\
$\mathrm{Na}_{2} \mathrm{O}$ & $\mathrm{O} .55$ & 0.32 & 0.27 & 0.34 & 0.25 & 0.36 & $0.25-0.55$ & 0.39 \\
$\mathrm{~K}_{2} \mathrm{O}$ & 0.16 & 0.17 & 0.43 & 0.19 & 0.14 & 0.11 & $0.11-0.43$ & 0.20 \\
$\mathrm{CaO}$ & 9.30 & 9.59 & 9.50 & 9.30 & 9.45 & 9.32 & $9.30-9.59$ & 9.41 \\
$\mathrm{MgO}$ & 9.67 & 10.12 & 9.68 & 10.24 & 9.60 & 10.03 & $9.60-10.24$ & 9.90 \\
$\mathrm{MnO}$ & 0.23 & 0.24 & 0.20 & 0.19 & 0.18 & 0.19 & $0.18-0.24$ & 0.20 \\
$\mathrm{Fe}_{2} \mathrm{O}_{3}$ & 11.83 & 12.60 & 11.48 & 12.56 & 12.50 & 12.50 & $11.48-12.60$ & 12.24 \\
$\mathrm{FeO}^{2}$ & 4.03 & 4.34 & 5.49 & 5.60 & 4.38 & 5.53 & $4.03-5.60$ & 4.89 \\
$\mathrm{TiO}_{2}$ & 0.68 & 0.38 & 0.39 & 0.56 & 0.37 & 0.65 & $0.37-0.65$ & 0.50 \\
$\mathrm{P}_{2} \mathrm{O}_{5}$ & 0.11 & 0.10 & 0.10 & 0.12 & 0.11 & 0.10 & $0.10-0.12$ & 0.10 \\
$\mathrm{H}_{2} \mathrm{O}$ & 0.62 & 0.85 & 0.89 & 0.90 & 0.64 & 0.79 & $0.62-0.90$ & 078 \\
$\mathrm{TOTAL}$ & 100.33 & 101.49 & 101.21 & 100.38 & 101.01 & 100.07 & & 100.76 \\
\hline
\end{tabular}


Table 2. Published Analytical Results of Other Comparable Amphibolites Rocks

\begin{tabular}{|cccccccc|}
\hline Oxides $(\%)$ & $*$ & 1 & 2 & 3 & 4 & 5 & 6 \\
$\mathrm{SiO}_{2}$ & 50.15 & 47.11 & 51.40 & 47.35 & 47.21 & 49.0 & 51.2 \\
$\mathrm{TiO}_{2}$ & 0.50 & 2.05 & 0.96 & 1.24 & 2.41 & 1.41 & 1.09 \\
$\mathrm{Al}_{2} \mathrm{O}_{3}$ & 12.00 & 13.31 & 12.51 & 11.85 & 11.94 & 13.25 & - \\
$\mathrm{Fe}_{2} \mathrm{O}_{3}$ & 12.24 & - & 8.55 & $0.43-$ & 9.65 & 8.20 & 9.4 \\
$\mathrm{FeO}$ & 4.89 & - & 1.26 & $9.50-$ & 2.17 & 2.36 & 1.4 \\
$\mathrm{MgO}$ & 9.90 & 0.59 & 6.36 & 0.99 & 7.82 & 6.36 & 6.4 \\
$\mathrm{CaO}$ & 9.41 & 11.08 & 12.16 & 6.35 & 10.20 & 9.75 & 10.7 \\
$\mathrm{Na} 2$ & 0.39 & 1.65 & 2.19 & 0.90 & 2.77 & 2.07 & 2.8 \\
$\mathrm{~K}_{2} \mathrm{O}$ & 0.20 & 0.28 & 0.51 & 0.04 & 0.56 & 0.25 & 0.20 \\
$\mathrm{P}_{2} \mathrm{O}_{5}$ & 0.10 & 0.52 & 0.14 & 0.33 & 0.22 & 0.19 & 0.14 \\
$\mathrm{MnO}$ & 0.20 & 0.26 & 0.22 & 0.23 & 0.12 & 0.19 & 0.22 \\
\hline
\end{tabular}

* = Average chemical composition of Zungeru amphibolites

1. = Average chemical composition of Illesha amphibolites [25].

2. = Average chemical composition of Allawa laminated amphibolites [26].

3. = Average chemical composition of Allawa massive amphibolites [26).

4. = Average chemical composition of Holleindalen Greenstone, amphibolites, Norway [27].

5. = Average chemical composition of Achaean metabasalt, superior province, Canada Shield [28].

6. = Average chemical composition of Achaean metabasalt, Norseman W. Australia [29].

The analytical results of amphibolite rock samples reveal an average composition of $\mathrm{SiO}_{2}$ values of $50.15 \%$. This value is comparable to those of Allawa laminated amphibolites [26], Achaean metabasalt, superior province, Canada Shield [28] and Achaean metabasalt, Norseman W. Australia [29]. The value of $\mathrm{SiO}_{2}$ in Zungeru amphibolites is however, higher than those of Illesha amphibolites [25], Allawa massive amphibolites [26] and Holleindalen Greenstone, amphibolites, Norway [27]. Average $\mathrm{Al}_{2} \mathrm{O}_{3}$ in the samples is $12 \%$ and is similar to amphibolites rocks samples of Illesha amphibolites[25], Allawa massive and Allawa laminated amphibolites[26], Achaean metabasalt, superior province, Canada Shield[28] and Achaean metabasalt, Norseman W. Australia [29], while the $\mathrm{Fe}_{2} \mathrm{O}_{3}$ value is higher than those of the Allawa laminated amphibolites [26), Holleindalen Greenstone, amphibolites, Norway[27], Achaean metabasalt, superior province, Canada Shield [28] and Achaean metabasalt, Norseman W. Australia[29] as computed in tables 1 and 2.The amphibolites are enriched in alumina and silica but depleted in iron and $\mathrm{CaO}$. This enrichment in alumina and silica and depletion in iron and $\mathrm{CaO}$ may be interpreted as formation of amphibolites from the sedimentary parent rocks. Average $\mathrm{K}_{2} \mathrm{O}$ value is $0.20 \%$ while $\mathrm{Na}_{2} \mathrm{O}$ is $0.30 \%$. Average $\mathrm{TiO}_{2}$ and $\mathrm{MgO}$ values in the samples are $0.50 \%$ and $9.90 \%$ respectively. $\mathrm{TiO}_{2}$ value is lower than all other comparable amphibolite rock samples, while $\mathrm{MgO}$ value is higher than all others stated (Table 2).

A plot of $\mathrm{SiO}_{2}$ against $\mathrm{Na}_{2} \mathrm{O}+\mathrm{K}_{2} \mathrm{O}$ [30], shows that Zungeru amphibolies are sub-alkaline and are similar to Allawa massive amphibolites [26] and Illesha amphibolites [25] but different from Allawa laminated amphibolites[26] and Holleindalen Greenstone, amphibolites, Norway[27] which are alkaline in nature (figure 8). The Zungeru amphibolites plot in sedimentary field like other comparable rocks as demonstrated in $\mathrm{Na}_{2} \mathrm{O} / \mathrm{Al}_{2} \mathrm{O}_{3}$ against the $\mathrm{K}_{2} \mathrm{O} / \mathrm{Al}_{2} \mathrm{O}_{3}$ diagram[31] (figure 9). Comparable rocks samples which plotted in the $\mathrm{Na}_{2} \mathrm{O} / \mathrm{Al}_{2} \mathrm{O}_{3}$ against $\mathrm{K}_{2} \mathrm{O} / \mathrm{Al}_{2} \mathrm{O}_{3}$ diagram were however, contradicted in the $\mathrm{Na}_{2} \mathrm{O}+\mathrm{K}_{2} \mathrm{O}$ versus $100 \times \mathrm{K}_{2} \mathrm{O} /$ $\mathrm{Na}_{2} \mathrm{O}+\mathrm{K}_{2} \mathrm{O}$ variation diagram [32] where they plot in the igneous field (Figure 10). Samples of the Zungeru amphibolites rock plotted on $\mathrm{Na}_{2} \mathrm{O}+\mathrm{K}_{2} \mathrm{O}$ versus $100 \times \mathrm{K}_{2} \mathrm{O}$ / $\mathrm{Na}_{2} \mathrm{O}+\mathrm{K}_{2} \mathrm{O}$ variation diagram confirm a sedimentary origin. This conforms to the $\mathrm{Na}_{2} \mathrm{O} / \mathrm{Al}_{2} \mathrm{O}_{3}$ against the $\mathrm{K}_{2} \mathrm{O} / \mathrm{Al}_{2} \mathrm{O}_{3}$ diagram earlier discussed. Elueze and Okunola [19] worked on the Burum amphibolites and their results showed that the rocks had a sedimentary protolith which is in agreement with this work. Based on the above discussions, it can be suggested that the Zungeru amphibolites are derived from sedimentary environment.

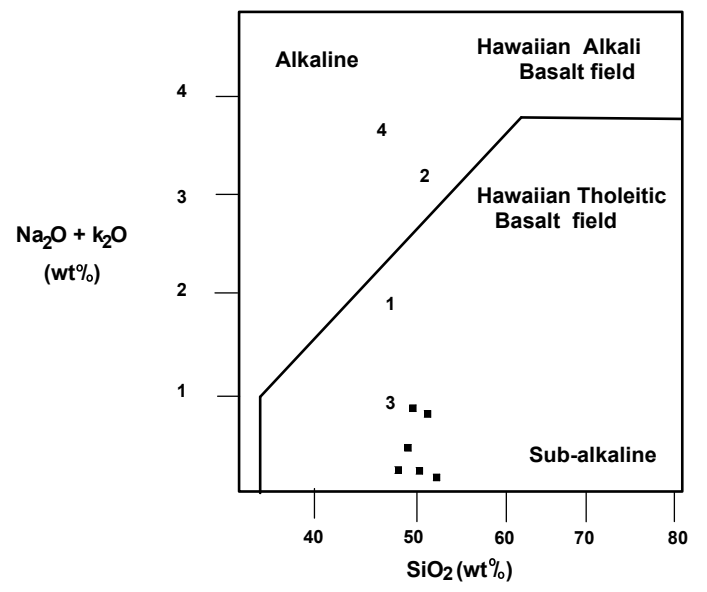

Figure 8. $\mathrm{Na} 2 \mathrm{O}+\mathrm{K} 2 \mathrm{O}$ versus $\mathrm{SiO} 2$ diagram for Zungeru amphibolites with other comparable rock samples [30].

- = Zungeru amphibolites.

1. =Illesha amphibolites [25].

2. = Allawa laminated amphibolites [26].

3. = Allawa massive amphibolites [26].

4. $=$ Holleindalen Greenstone, amphibolites, Norway [27]. 


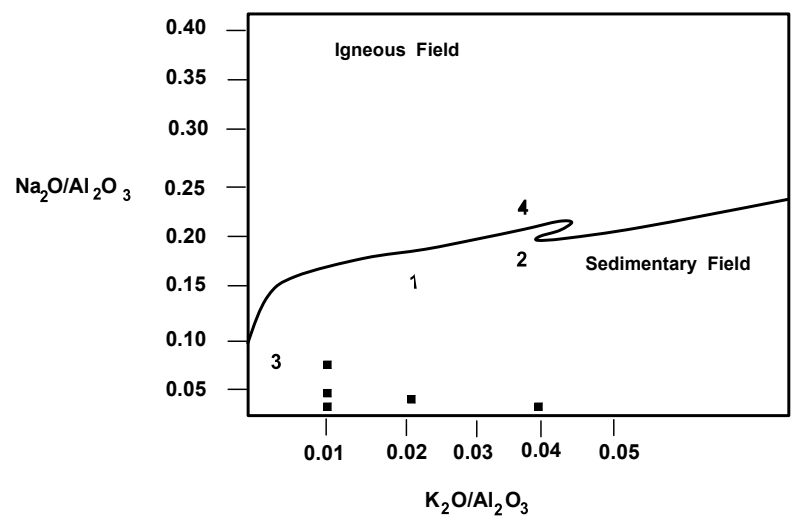

Figure 9. $\mathrm{Na}_{2} \mathrm{O} / \mathrm{Al}_{2} \mathrm{O}_{3}$ Versus $\mathrm{K}_{2} \mathrm{O} / \mathrm{Al}_{2} \mathrm{O}_{3}$ for Zungeru amphibolites [31].

$=$ Zungeru amphibolites.

= Illesha amphibolites [25].

= Allawa laminated amphibolites [26].

$=$ Allawa massive amphibolites [26].

= Holleindalen Greenstone amphibolites, Norway [27].

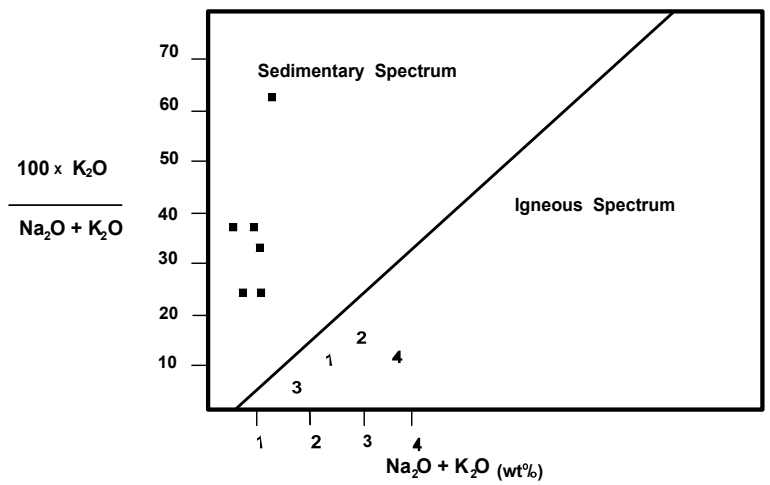

Figure 10. $\mathrm{Na}_{2} \mathrm{O}+\mathrm{K}_{2} \mathrm{O}$ versus $100 \times \mathrm{K}_{2} \mathrm{O} / \mathrm{Na}_{2} \mathrm{O}+\mathrm{K}_{2} \mathrm{O}$ of Zungeru amphibolites and other comparable rocks [32].

$=$ Zungeru amphibolites.

= Illesha amphibolites [25].

= Allawa laminated amphibolites [26].

= Allawa massive amphibolites [26].

= Holleindalen Greenstone, amphibolites, Norway [27].

\section{Conclusions}

The origin of amphibolites can be determined, mineralogically by their constituent mineral composition, structurally by the presence of certain structural and textural associations within the rocks and geochemically by the analyses of constituent oxides and trace elements present in the rocks. The investigation into the part of Zungeru basement complex rocks revealed rocks of migmatite-gneiss complex, mica schists, amphibolites and minor intrusive such as quartz veins and pegmatites. Three petrographic types of amphibolites; massive, banded and schistose varieties were distinguished base on their distinctive textural and mineralogical characteristics. These petrographic variations tend to have a bearing on their petrochemical character as defined by major element ratio. Despite the textural and chemical distinctions, acquired data show that the Zungeru amphibolites are derived from sedimentary environment. The binary plot of $\mathrm{Na}_{2} \mathrm{O} / \mathrm{Al}_{2} \mathrm{O}_{3}$ versus $\mathrm{K} 2 \mathrm{O} / \mathrm{Al}_{2} \mathrm{O}_{3}$ indicates a sedimentary origin for the Zungeru amphibolites [31]. This research project has revealed the origin (protolith), chemical composition and petrography of Zungeru amphibolites as well as geological history of the study area. This is an indication that the aims and objectives of the study have been fully accomplished.

\section{Acknowledgements}

I thank Professor M. I. Ogunbajo, of the department of Geology, Federal University of Technology, Minna, Nigeria who supervised my master thesis that provided the opportunity to do a similar work on amphibolites in this study.

\section{REFERENCES}

[1] Ajibade, A. C. The origin of Older Granites of Nigeria, some evidence from Zungeru Region, Jour. Min. and Geolo, Vol.19, Pp. 223-230, 1982.

[2] Jones, H. A and Hockey R. D. The Geology of part of South-Western Nigeria. Explanation of 1:250,000 sheet 59-65, Geol. Surv. Nigeria, Bull. 31, 87pp, 1964

[3] Grant, N. K. The Late Precambrian to early Paleozoic Pan-African Orogeny in Ghana, Togo, Dahomey and Nigeria, Geol.Soc. Am. Bull. Vol. 80, Pp 45-56, 1969.

[4] McCurry, P. The Geology of the Precambrian to Lower Paleozoic rocks of northern Nigeria: a review. In Kogbe, C. A. (Ed.), Geology of Nigeria. Elizabethan Pub. Co. Lagos, pp. 15-39, 1976.

[5] Rahaman, M.A. Review of the Basement Geology of South Western Nigeria Geology of Nigeria. In Kogbe, C. A. (Ed.). Geology of Nigeria. Elizabethan Publishing Company, Lagos, pp. 41-58, 1976.

[6] Ekwueme, B.N. Geology of the area around Obudu Cattle Ranch, Southeastern Nigeria. J. Min. Geol. 27 (1), Pp. 129-134, 1991.

[7] Muotoh, E. O. G., Oluyide, P. O., Okoro, A. U.and Mogbo, O. E. The Muro Hills Banded Iron Formation. Geological Survey Annotated Reports, 135, pp15-25, 1988.

[8] Ekwueme, B.N. The structural orientations and Precambrian deformational Episodes of Uwet, Oban Massif, S. E. Nigeria. Prec. Res. 34:269-289, 1987.

[9] Russ, W. The Geology of parts of Niger, Zaria and Sokoto Provinces (with Special Reference to Gold), Bull. Geolo. Surv. Nigeria, No. 27, 1957.

[10] Truswell, F. and Cope. R. N. (1963). The Geology of parts of Niger and Zaria Provinces, Northern Nigeria. Bull. Geol. Surv. of Nigeria, No. 29, 1963..

[11] Oyawoye, M.O. The Geology of the Nigerian Basement Complex, Nigeria, J. Min. Geol. and metal. Soc. (1), Pp. 7-102, 1964. 
[12] Ajibde, A. C., Fitches, W. R. and Wright, J. B. The Zungeru Mylonites, Nigeria: recognition of a major tectonic unit. Rev. Geol. Dyn. Geog. Phys. Vol. 21(5), pp359-363, 1979.

[13] Falconer, J.D. The Geology and Geography of Northern Nigeria. Macmillian, London, 295p. 1911.

[14] Ajibade, A. C., Anyanwu. N. P. C., Okoro, A. U. The Geology of Minna Area (explanation of 1:250,000 Sheet 42 (Minna). Nigeria Geolo. Surv. Agency, Bull. No. 43, 112p, 2008.

[15] Okunlola, O. A., Adeigbe, O. C. and Oluwatoke, O. O. Compositional and Petrogenetic features of Schistose Rocks of Ibadan Area, Southwestern Nigeria. Earth Sciences Research Journal, Vol. 13, (2), pp 119-133, 2009.

[16] Akindele, O. O. Geology and Geochemistry of some Crystalline Basement Complex Rocks in Illesha area, southwestern Nigeria: Implication on Provenance and Evolution. Pak. Jour. Sci. Ind. Res. Vol. 50, No.4, pp 223-231, 2007.

[17] Muhammad, A. K., Saif, U. R., Muhammad, F. U. and Naveed, A. Geochemistry and Tectonic Environments of Babusar Amphibolites in Southeast Kohistan, Pakistan. Geol.Bull. Punja Univ. (44), pp. 105-116, 2009.

[18] Ndukauba, E. and Ukaegbu, V. U. Petrologic and Structural features of basement rocks of parts of Mukuru area, southweatern Nigeria. Earth Science, Science PG 2 (4): pp. 69-103, 2013.

[19] Elueze, A. A. and Okunlola, O. A. Geochemical Features and Petrogenetic affinity of Precambria Amphibolites of Burum Area, Central Nigeria. J. Min, Geolo. Vol.39(2), pp. 71-78, 2003.

[20] Leake, B.E. The Chemical distinction between Ortho- and Para - Amphibolites. J. Petrol., Vol. 5, pp.238-254, 1964.

[21] Evans, B.W and Leake, B. E. The composition and origin of striped amphibolites of Connemara, Ireland. Journal of petrology, Vol.1. Pp.337-363,1960.

[22] Gates, R.M. Amphibolites - Syntectonic Intrusives. Am. J. Sci. Vol. 265, Pp.118-131, 1967.
[23] Van de Camp, P.C. Origin of Amphibolites in beartooth Mountain, Montana and Wyoming: New Data and Interpretation: Geological Society of America Bulletin, Vol. 80, p. $1127-1136,1969$

[24] Qing, L., Quanlin, H., Liewen, X., Shanqin, N. and Yudong, W. Different Origins of the Fractionation of Platinum- GroupElements in Raobazhan and Bixiling Mafic - Ultramafic Rocks from the Dabie Orogen, Central China. Jour. Geolo. Res. Vol.2012, Article ID 631426, 11p, 2012.

[25] Olade, M.A. and Elueze, A.A. (1979). Petrochemistry of Illesha Amphibolites and Precambrian Crustal Evolution in the Pan-African Domain of Southwestern Nigeria. Precambrian Research, 8, Pp.308-318, 1979.

[26] Elueze, A.A. Petrochemical and petrogenetic characteristics of Precambrian amphibolites of Allawa District, North Western Nigeria. Chemical Geol, Pp. 12-14, 1985.

[27] Elliot, R. D. and Couwan, D. R. The Petrochemistry of the amphibolites of the Holleindain Greenstone Group. John Beimen, Norway. Norsk. Geolo. Tidsskr, 45, pp309-325, 1966.

[28] Glickson, A.Y. Primitive Archean Element Distribution Patterns: Chemical Evidence and Geochemical significant. Earth Planet. Sci. Lett. 12: 309-20, 1967

[29] Hallberg, J. A. Geochemistry of Archean Volcanic Belts in the Eastern Gold Field Region of Western Australia. Jour. Petrology. 13: pp. 120-136, 1972.

[30] Irvine, T. N and Barager, W. R. A. A guide to chemical classification of common volcanic rocks. Can. J. Earth.Sci.Vol. 8, Pp. 523-548, 1971.

[31] Garrels, R. M and Mackenzie, F. F. Evolution of sedimentary rocks. W.M. Noron and Co., New York, 394p, 1971.

[32] Honkamo, M. Geochemistry and Tectonic Setting of Early Proterozoic Volcanic Rocks in Northen Osthuthoria, Finland. In Pharoah, T. C., Beckinsale, R. D. and Richard D. (eds.). Geochemistry and Mineralisation of Proterozoic Volcanic Suites, Geol. Soc. Spec. Publ. No. 38, 1987. 